\title{
Metabolism of Citric Acid, Potassium Citrate, Sodium Citrate and Calcium Citrate in the Rat
}

\author{
(Received December 13, 1986) \\ Yumiko Nakamura, Yasuhide TonogaI, Sumiko TsujI and Yoshio Ito \\ (National Institute of Hygienic Sciences, Osaka Branch; \\ 1-1-43, Hoenzaka, Higashi-ku, Osaka, Japan)
}

\begin{abstract}
The metabolism of citric acid and potassium, sodium and calcium salts of citrate in rats was investigated by single-dose oral administration. The per capita daily intake of citric acid and its salts in Japanese was estimated to be $37.78 \mathrm{mg} / \mathrm{kg}$ by Ito et al., so $37.78 \mathrm{mg} / \mathrm{kg}$ was chosen as the low dose and $1,889 \mathrm{mg} / \mathrm{kg}$ (50 times more) as the high dose. The urinary excretion of citrate, expiratory carbon dioxide $\left(\mathrm{CO}_{2}\right)$, and the blood concentration and tissue distribution of citrate and/or its metabolites were investigated in fasting rats. A large proportion of administered citric acid and its salts was excreted within 24 hours, i.e., 76.7 to $88.9 \%$ as expiratory $\mathrm{CO}_{2}, 3.8$ to $11.2 \%$ in urine, and only a small amount in feces. In the rats given the high dose of potassium or sodium citrate, the absorption rate of citrate decreased while the urinary excretion increased. The times at which the urinary excretion of citrate and the blood concentration of citrate and/or its metabolites reached the maximum were different for citric acid and its salts. The absorption rates of citric acid and its salts were considered to be in the following order: citric acid $>$ potassium citrate $\geqq$ sodium citrate $>$ calcium citrate. The distribution in the gastrointestinal tract was 37.6 to $64.3 \%$ after 30 minutes but less than $2.7 \%$ after 24 hours. Therefore, it is clear that a large proportion of administered citric acid and its salts is absorbed, metabolized and excreted mainly as $\mathrm{CO}_{2}$, and that the difference in metabolism between citric acid and its alkaline salts is negligible.
\end{abstract}

Key words: metabolism; citric acid; potassium citrate; sodium citrate; calcium citrate; urinary citrate; expiratory carbon dioxide; ${ }^{14} \mathrm{C}$-radioactivity

\section{Introduction}

Citric acid is an intermediary substance in oxidative metabolism, being a component of the tricarboxylic acid cycle. Citric acid and its salts occur in many foods, and are normal metabolites in the body ${ }^{1), 2)}$. Citric acid and its salts are widely used as food additives in Japan. For example, citric acid is used as an acidulant, sodium citrate as a seasoning, and calcium citrate as a dietary supplement ${ }^{3)}$. Recently it has been suggested that the percentage of sodium salts in food additives is too high. The Ministry of Health and Welfare of Japan recommends the replacement of sodium salts with other salts such as potassium salts from the viewpoint of the prevention of hypertension. Potassium citrate has been permitted as a food additive in the United States of America ${ }^{1,4)}$ but not in Japan.
Thus, we investigated the metabolism of citric acid, potassium citrate, sodium citrate and calcium citrate in the rat, in order to elucidate possible differences in metabolism between potassium citrate and sodium citrate.

\section{Materials and Methods}

Citric acid and tripotassium citrate were purchased from Ishizu Pharmaceutical Co., Ltd. (Osaka), trisodium citrate from Nakarai Chemicals, Ltd. (Kyoto), and calcium citrate from Yoneyama Chemical Industries Ltd. (Osaka). They were all of guaranteed reagent grade. [1,5${ }^{14} \mathrm{C}$ ]Citric acid (specific activity $64.7 \mu \mathrm{Ci} / \mathrm{nmol}$ ), Aquasol-2 ${ }^{\circledR}$ and Protosol ${ }^{\circledR}$ were purchased from New England Nuclear (Boston, Mass). Other reagents were of guaranteed grade.

A system consisting of a Shimadzu LC-6A, 


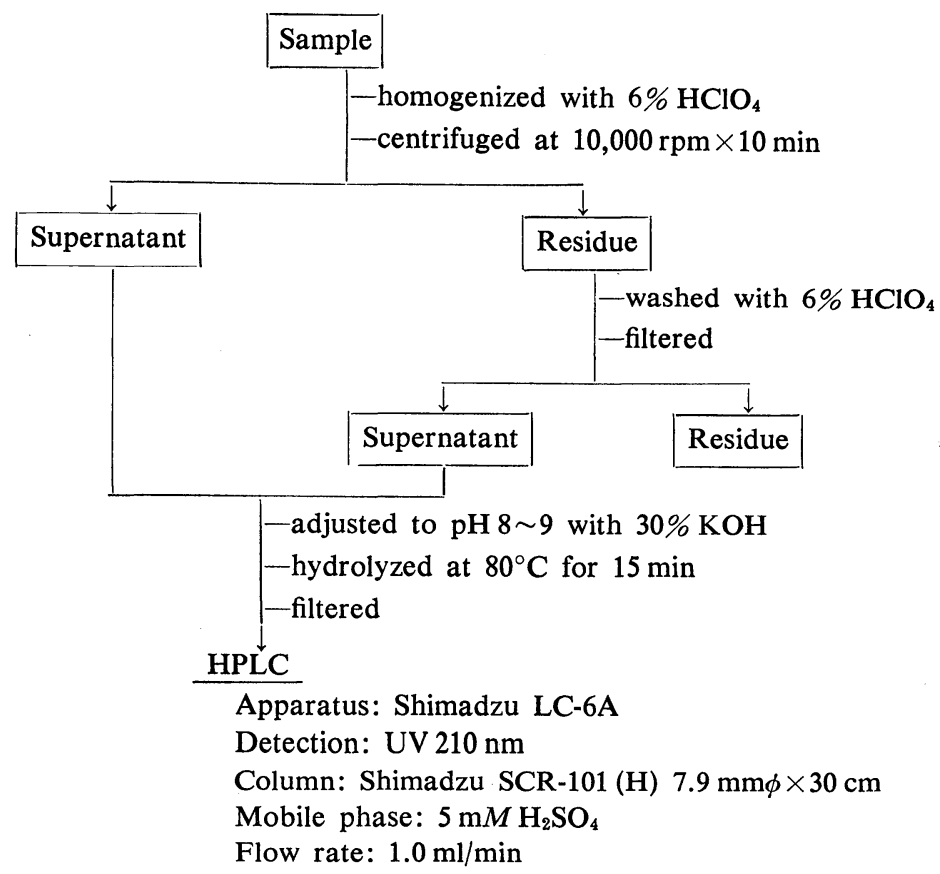

Scheme 1. Procedure for analysis of citric acid by HPLC

Shimadzu SPD-6AV and Shimadzu SCR-101 (H) $(7.9 \mathrm{~mm} \phi \times 30 \mathrm{~cm})$ (Shimadzu Seisakusho, Kyoto) was used for the analysis of urinary citrate by HPLC. ${ }^{14} \mathrm{C}$-Radioactivity was counted with an Aloka liquid scintillation spectrometer, model LSC-673 (Aloka Co., Ltd., Tokyo).

Male Slc: Wister rats (Shizuoka Laboratory Animal Center) were acclimated in an air-conditioned room for more than 1 week before use. Rats were housed in a Metabolica ${ }^{\circledR} \mathrm{CO}-2$ system (Sugiyamagen Iriki Co. Ltd., Tokyo) after the administration of ${ }^{14} \mathrm{C}$-containing citrates. Rats weighing $150 \sim 200 \mathrm{~g}$ were used in the following experiments.

The rats were fasted overnight before use and the experiments were carried out in the fasting state; water was allowed ad libitum.

Ito et al. ${ }^{5)}$ estimated the per capita daily intake of citrate of Japanese to be $37.78 \mathrm{mg} / \mathrm{kg}$. Thus, the doses for oral administration (calculated as citric acid) were set at $37.78 \mathrm{mg} / \mathrm{kg}$ for the low dose and $1889 \mathrm{mg} / \mathrm{kg}$ (50 times the low dose) for the high dose.

Experiment 1. Time course of urinary excretion of citrate

Citric acid, tripotassium citrate, trisodium citrate, and calcium citrate were each dissolved or suspended in water, and the following samples (high dose) were prepared: citric acid, 1889 $\mathrm{mg} / 5 \mathrm{ml} / \mathrm{kg}$; potassium citrate, $1889 \mathrm{mg} / 5 \mathrm{ml} / \mathrm{kg}$; sodium citrate, $1889 \mathrm{mg} / 7.5 \mathrm{ml} / \mathrm{kg}$; calcium citrate, $1889 \mathrm{mg} / 7.5 \mathrm{ml} / \mathrm{kg}$.

Fifteen rats were divided into 5 groups of 3 each. Rats were housed individually in metabolic cages after oral administration of the samples. Distilled water was administered orally to the 3 rats of the control group. Urine was collected at constant intervals, and the total amount of citrate in urine was analyzed by the method summarized in Scheme 1. Briefly, urine was treated with 10 volumes of $6 \%$ perchloric acid $^{8}$ and centrifuged. The supernatant was adjusted to $\mathrm{pH} 8 \sim 9$ with $30 \%$ potassium hydroxide and hydrolyzed at $80^{\circ} \mathrm{C}$ for 15 minutes. Then, the solution was filtered and the filtrate was assayed by the HPLC method ${ }^{7)}$. The conditions of HPLC were as follows:

Apparatus: Shimadzu LC-6A

Detector: Shimadzu SPD-6 AV UV $210 \mathrm{~nm}$

Column: Shimadzu SCR-101 (H) $7.9 \mathrm{~mm} \phi$ $\times 30 \mathrm{~cm}$

Mobile phase: $5 \mathrm{mM}$ sulfuric acid 


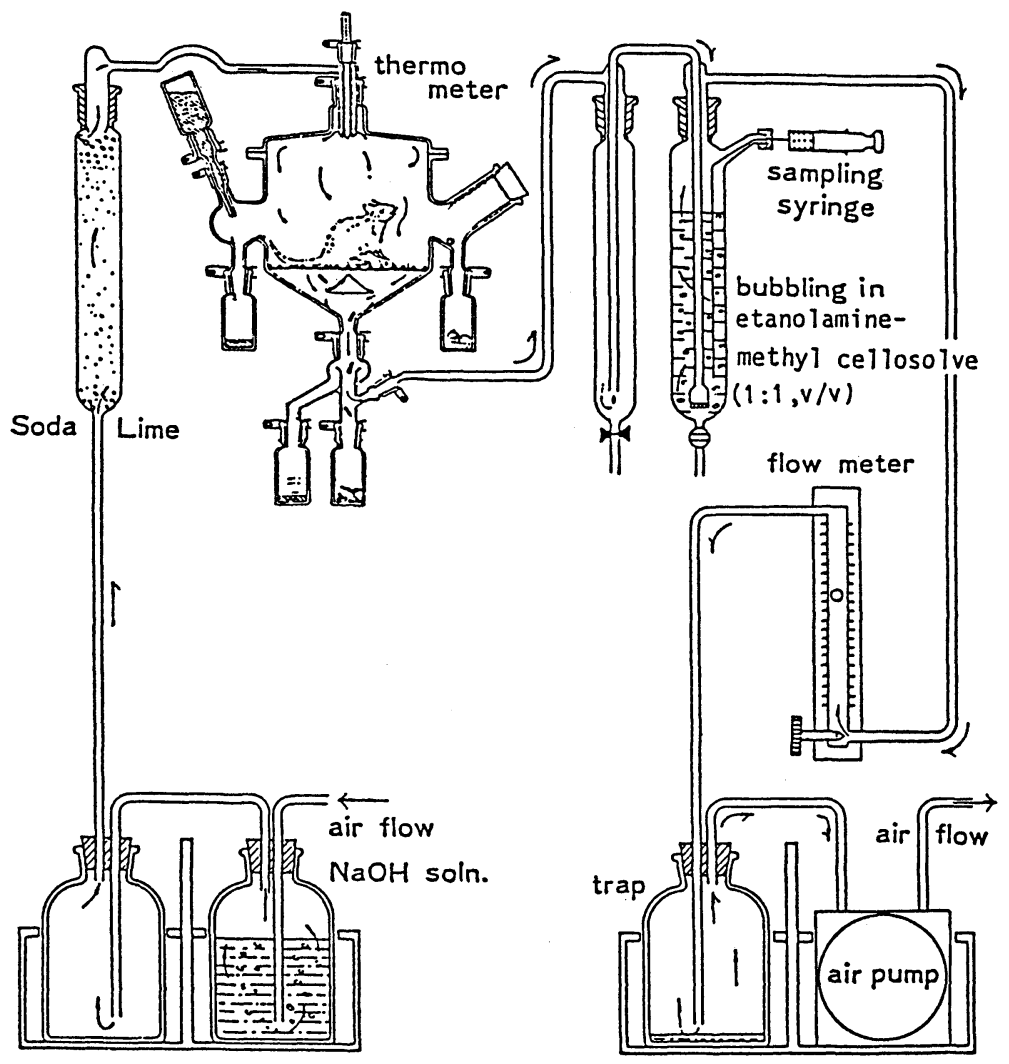

Fig. 1. Diagram of the apparatus for the estimation of expiratory ${ }^{14} \mathrm{CO}_{2}$

Experiment 2. Expiratory ${ }^{14} \mathrm{CO}_{2}$, and urinary and fecal excretions of ${ }^{14} \mathrm{C}$-citrate and/or its metabolites

$\left[1,5-{ }^{14} \mathrm{C}\right]$ Citric acid was mixed with equivalent amounts of potassium hydroxide, sodium hydroxide, and calcium hydroxide to prepare the potassium, sodium, and calcium salts of [1,5${ }^{14} \mathrm{C}$ ]citric acid, respectively. The ${ }^{14} \mathrm{C}$-labeled citric acid and its salts were diluted with the corresponding non-labeled citric acid and its salts, and the following samples for oral administration were prepared. Low dose: citric acid, $37.78 \mathrm{mg} / 5 \mu \mathrm{Ci} / 5.5 \mathrm{ml} / \mathrm{kg}$; potassium citrate, 37.78 $\mathrm{mg} / 5 \mu \mathrm{Ci} / 5.5 \mathrm{ml} / \mathrm{kg}$; sodium citrate, $37.78 \mathrm{mg} / 5$ $\mu \mathrm{Ci} / 5.5 \mathrm{ml} / \mathrm{kg}$; calcium citrate, $37.78 \mathrm{mg} / 5 \mu \mathrm{Ci} /$ $5.5 \mathrm{ml} / \mathrm{kg}$. High dose: potassium citrate, 1889 $\mathrm{mg} / 5 \mu \mathrm{Ci} / 5.5 \mathrm{ml} / \mathrm{kg}$; sodium citrate, $1889 \mathrm{mg} / 7.5$ $\mu \mathrm{Ci} / 8.25 \mathrm{ml} / \mathrm{kg}$. Rats were housed in metabolic cages (Fig. 1) after oral administration of a ${ }^{14} \mathrm{C}$ containing sample. Air flow was $1 \mathrm{~L} / \mathrm{min}$, and the expiratory ${ }^{14} \mathrm{CO}_{2}$ was trapped in $200 \mathrm{ml}$ of methylcellosolve-ethanolamine $(1: 1, \mathrm{v} / \mathrm{v})$. One $\mathrm{ml}$ of the ${ }^{14} \mathrm{CO}_{2}$-trapping solution was sampled at constant intervals, and the ${ }^{14} \mathrm{C}$-radioactivity was measured according to the method of Mogi et al. ${ }^{8)}$.

Feces and urine were collected individually for 24 or 48 hours after oral administration. To $50 \mu \mathrm{l}$ of urine were added $1 \mathrm{ml}$ of water, $5 \mathrm{ml}$ of methanol and $10 \mathrm{ml}$ of Aquasol- ${ }^{\circledR}$, and the ${ }^{14} \mathrm{C}$ radioactivity in urine was measured with a scintillation counter using an external standardization method. Feces were homogenized with 10 volumes of water. A suitable amount of the homogenate (containing about $3 \mathrm{mg}$ of feces) was solubilized with $2 \mathrm{ml}$ of Protosol ${ }^{\circledR}-n$ butanol $(1: 1, \mathrm{v} / \mathrm{v})$ mixture, and decolorized with $0.5 \mathrm{ml}$ of $30 \%$ hydrogen peroxide, then $0.6 \mathrm{ml}$ of $1 \mathrm{~N}$ hydrochloric acid and $10 \mathrm{ml}$ of Aquasol$2^{\circledR}$ were added, and the ${ }^{14} \mathrm{C}$ radioactivity was measured as described above.

Experiment 3. Blood concentration of ${ }^{14} \mathrm{C}$-citrate and/or its metabolites as a function of time 
The administered samples were prepared by the method described in Experiment 2. The dose of samples for oral administration (calculated as citric acid) was as follows. Low dose: citric acid, $37.78 \mathrm{mg} / 10 \mu \mathrm{Ci} / 6 \mathrm{ml} / \mathrm{kg}$; potassium citrate, $37.78 \mathrm{mg} / 10 \mu \mathrm{Ci} / 6 \mathrm{ml} / \mathrm{kg}$; sodium citrate, 37.78 $\mathrm{mg} / 10 \mu \mathrm{Ci} / 6 \mathrm{ml} / \mathrm{kg}$; calcium citrate, $37.78 \mathrm{mg} / 10$ $\mu \mathrm{Ci} / 6 \mathrm{ml} / \mathrm{kg}$. High dose: potassium citrate, 1889 $\mathrm{mg} / 10 \mu \mathrm{Ci} / 6 \mathrm{ml} / \mathrm{kg}$; sodium citrate, $1889 \mathrm{mg} / 15$ $\mu \mathrm{Ci} / 9 \mathrm{ml} / \mathrm{kg}$.

The experiment was carried out in triplicate. Rats were housed in metabolic cages (Fig. 1) after administration of the ${ }^{14} \mathrm{C}$-containing samples. Blood samples were collected periodically from the tip of the tail, and the ${ }^{14} \mathrm{C}$ radioactivity was measured according to the method of Mogi et al. ${ }^{8)}$. The concentration of ${ }^{14} \mathrm{C}$-citrate and/or its metabolites was calculated assuming that the weight of whole blood accounts for $1 / 13$ of the body weight ${ }^{9}$.

Experiment 4. Distribution of ${ }^{14} \mathrm{C}$-citrate and/or its metabolites in tissues

Twelve rats were divided into 6 groups of 2 each and orally given 6 kinds of samples as described in Experiment 3. One rat in each group was killed after 30 minutes and the other rat was killed after 24 hours. At 30 minutes and 24 hours after administration, blood samples were collected from the jugular vein into a heparinized syringe under light diethylether anesthesia. Then, the liver, kidneys, lungs, stomach, small intestine, and large intestine (including their contents) were removed immediately. They were each homogenized with 10 volumes of water. The ${ }^{14} \mathrm{C}$ radioactivity in a suitable amount of each homogenate (containing $10 \sim 20 \mathrm{mg}$ of tissues) was measured by the same method as in the case of the fecal analysis described in Experiment 2.

\section{Results}

Experiment 1. Time course of urinary excretion of citrate

Amounts of urinary citrate excreted during 24 hours after oral administration of citric acid and its salts at the high dose are indicated in Table 1. Apparent excretion rate, defined as the ratio of excretion to administration, is also indicated in Table 1.

The amounts of urinary citrates in the potassium salt $(\mathbf{C K})$ administered group and sodium salt $(\mathrm{CNa})$ administered group were much higher than those in the control group, citric acid $(\mathrm{CH})$ administered group, and calcium citrate $(\mathrm{CCa})$ administered group. Volumes of urine were also increased in the $\mathrm{CK}$ and $\mathrm{CNa}$ group (data not shown). The apparent excretion rates showed similar trends.

Time courses of the urinary excretion rate per hour are illustrated in Fig. 2. The urinary excretion rate of citrates reached the maximum after $0 \sim 2$ hours in the $\mathrm{CH}$ and $\mathrm{CK}$ groups, after $2 \sim 4$ hours in the $\mathrm{CNa}$ group, and after $4 \sim 6$ hours in the $\mathrm{CCa}$ group. the excretion pattern of the CK administered group was somewhat different from that of the $\mathrm{CNa}$ administered group; the excretion started sooner and con-

Table 1. Body Weight and Urinary Excretion in 24 Hours

\begin{tabular}{|c|c|c|c|c|}
\hline \multirow[b]{2}{*}{ Group } & \multirow[b]{2}{*}{ Dose } & \multicolumn{2}{|c|}{$\mu \mathrm{Mol}$ eq. of citric acid } & \multirow{2}{*}{$\begin{array}{c}\text { Apparent excretion } \\
\text { rate }[\%]^{2)}\end{array}$} \\
\hline & & Administration & $\begin{array}{l}\text { Urinary } \\
\text { excretion }\end{array}$ & \\
\hline Control & - & 0 & $3.88 \pm 1.32^{1)}$ & - \\
\hline $\mathrm{CH}$ (HD) & \multirow{4}{*}{$1889 \mathrm{mg} / \mathrm{kg}$} & $1193 \pm 24$ & $14.1 \pm 1.2$ & $1.19 \pm 0.12$ \\
\hline $\mathrm{CK}$ (HD) & & $1200 \pm 12$ & $168 \pm 31$ & $14.0 \pm 2.7$ \\
\hline $\mathrm{CNa}$ (HD) & & $1245 \pm 12$ & $119 \pm 10$ & $9.55 \pm 0.77$ \\
\hline $\mathrm{CCa}(\mathrm{HD})$ & & $1324 \pm 9$ & $51.1 \pm 0.8$ & $3.86 \pm 0.09$ \\
\hline
\end{tabular}

Abbreviations: $\mathrm{CH}$, citric acid; $\mathrm{CK}$, tripotassium citrate; $\mathrm{CNa}$, trisodium citrate; $\mathrm{CCa}$, calcium citrate; HD, high dose

1) Results are represented as mean \pm SEM for three rats.

2) Apparent excretion rate $[\%]=\frac{\text { Urinary excretion }}{\text { Dose administered }} \times 100$ 


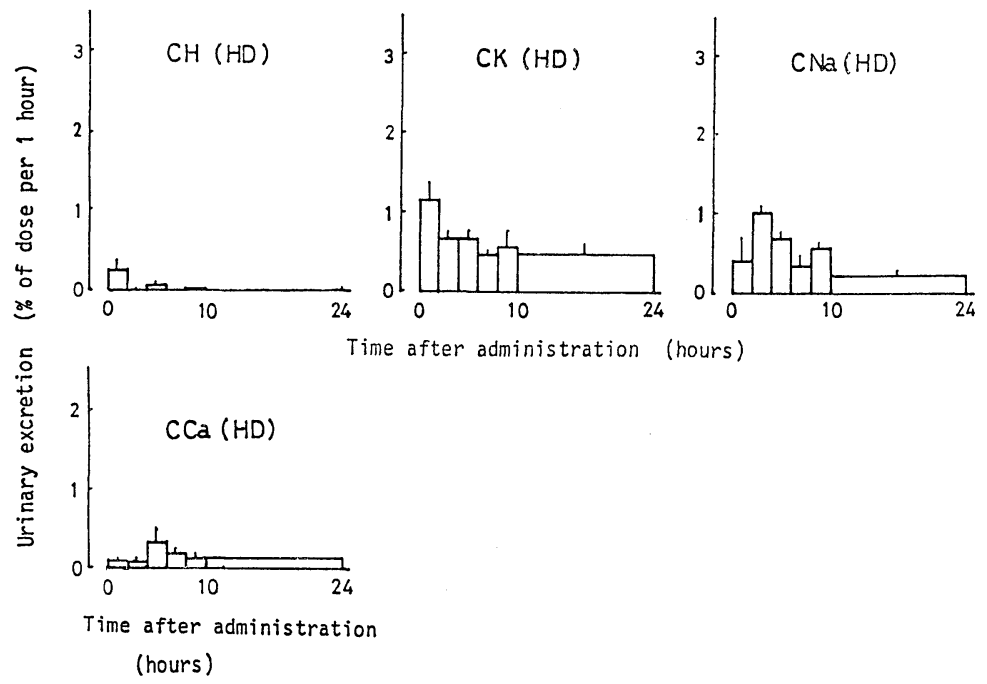

Fig. 2. Urinary excretion of citric acid as a function of time

Urinary excretion of citric acid is indicated as the percentage of citric acid excreted in urine per one hour with respect to the orally administered citric acid dose. Each column represents the mean of 3 animals and the vertical bar indicates the SEM.

Abbreviations: $\mathrm{CH}$, citric acid; $\mathrm{CK}$, tripotassium citrate; $\mathrm{ClNa}$, trisodium citrate; $\mathrm{CCa}$, calcium citrate

Table 2. Excretion of ${ }^{14} \mathrm{C}$ Radioactivity in Urine, Feces and Expiratory ${ }^{14} \mathrm{CO}_{2}$ in 24 Hours

\begin{tabular}{ccccccc}
\hline \hline \multirow{2}{*}{ Group } & \multirow{2}{*}{ Dose } & \multirow{2}{*}{$\begin{array}{c}\text { Time } \\
\text { [hours] }\end{array}$} & \multicolumn{3}{c}{ Excretion of ${ }^{14} \mathrm{C}$ ratioactivity $(\%$ of dose) } \\
\cline { 5 - 7 } & & & Expiratory ${ }^{14} \mathrm{CO}_{2}$ & Urine & Feces & Total \\
\hline $\mathrm{CH}$ (LD) & $37.78 \mathrm{mg} /$ & 24 & 88.9 & 5.0 & 0.1 & 94.0 \\
$\mathrm{CK}$ (LD) & $5 \mu \mathrm{Ci} / \mathrm{kg}$ & 24 & 88.2 & 5.4 & 0.7 & 94.3 \\
$\mathrm{CNa}$ (LD) & & 24 & 86.4 & 4.1 & 0.0 & 90.5 \\
$\mathrm{CCa}$ (LD) & & 24 & 83.6 & 3.8 & 0.7 & 88.1 \\
\hline $\mathrm{CK}$ (HD) & $1889 \mathrm{mg} /$ & 24 & 85.0 & 8.8 & - & 93.8 \\
& $5 \mu \mathrm{Ci} / \mathrm{kg}$ & 48 & 88.4 & 10.3 & 0.8 & 99.5 \\
$\mathrm{CNa}$ (HD) & & 24 & 76.7 & 11.2 & - & 87.9 \\
& & 48 & 81.8 & 11.8 & 2.8 & 96.4 \\
\hline
\end{tabular}

Abbreviations: $\mathrm{CH}$, citric acid; $\mathrm{CK}$, tripotassium citrate; $\mathrm{CNa}$, trisodium citrate; $\mathrm{CCa}$, calcium citrate; LD, low dose; HD, high dose

tinued for longer in the $\mathrm{CK}$ group than the $\mathrm{CNa}$ group.

Experiment 2. Expiratory ${ }^{14} \mathrm{CO}_{2}$ and urinary and fecal excretions of ${ }^{14} \mathrm{C}$-citrate and/or its metabolites

Table 2 indicates the expiratory ${ }^{14} \mathrm{CO}_{2}$ and urinary and fecal excretions of ${ }^{14} \mathrm{C}$-citrate and/ or its metabolites relative to the amount of administered ${ }^{14} \mathrm{C}$-citric acid and its salts over 24 or 48 hours. In all the groups, 76.7 to $88.9 \%$ of administered ${ }^{14} \mathrm{C}$-labeled citric acid and its salts was excreted as ${ }^{14} \mathrm{CO}_{2}$ within 24 hours. Fecal excretion was very low. In urine, 3.8 to $11.2 \%$ of the administered ${ }^{14} \mathrm{C}$-labeled citric acid and its salts was excreted. Total ${ }^{14} \mathrm{C}$-citrate and/or its metabolites excreted in expired air, urine, and feces accounted for 88.1 to $94.3 \%$ of the dose within 24 hours and 96.4 to $99.5 \%$ within 48 hours.

The proportion of urinary excretion was higher in the rats given the high dose than in the rats given the low dose. The urinary excretion 


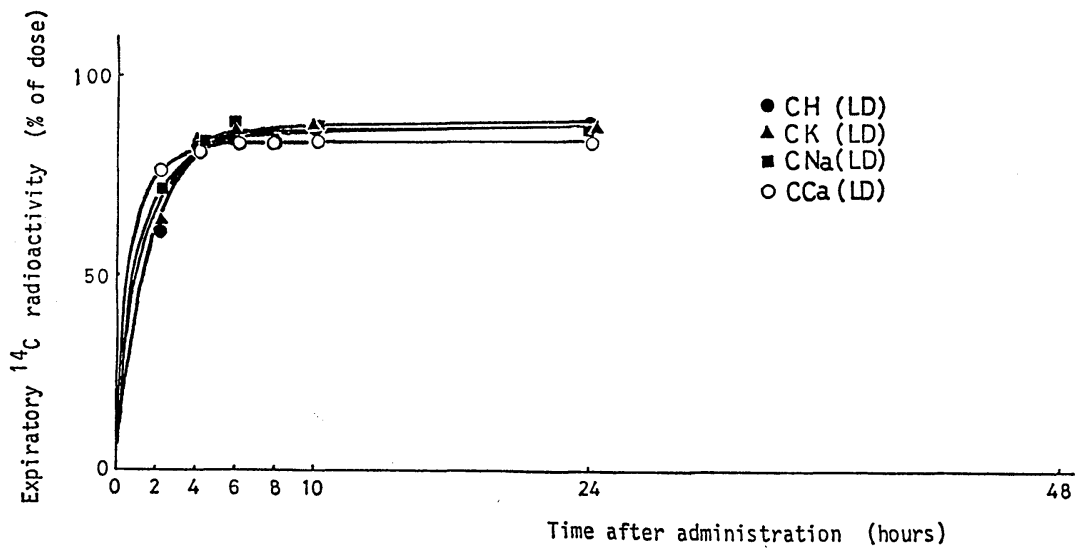

Fig. 3-A. Changes of the expiratory ${ }^{14} \mathrm{C}$ radioactivity as a function of time

Abbreviations: $\mathrm{CH}$, citric acid; $\mathrm{CK}$, tripotassium citrate; $\mathrm{CNa}$, trisodium citrate; $\mathrm{CCa}$, calcium citrate; $\mathrm{LD}$, low dose $(37.78 \mathrm{mg} / \mathrm{kg})$

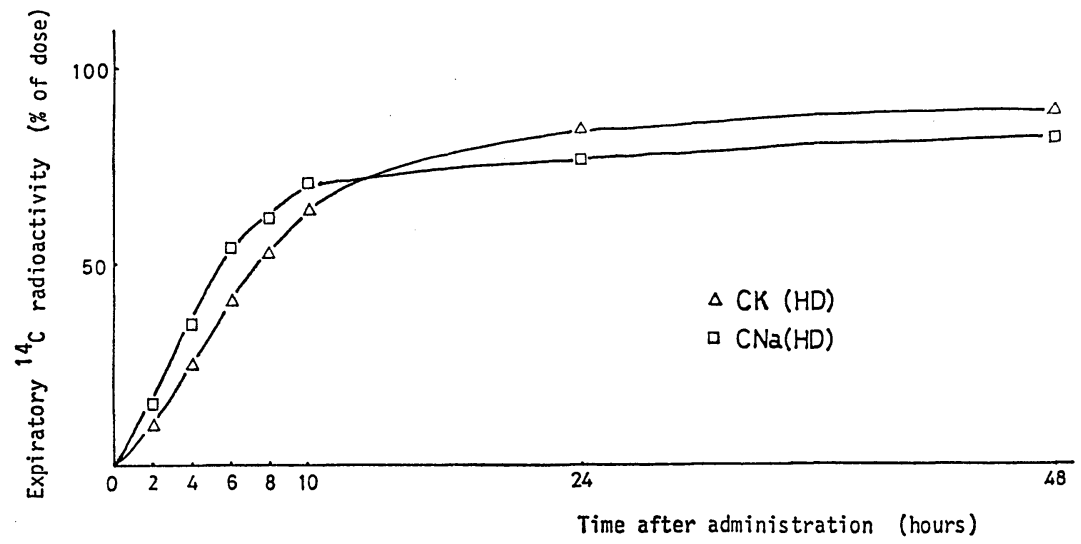

Fig. 3-B. Changes of the expiratory ${ }^{14} \mathrm{C}$ radioactivity as a function of time

Abbreviations: $\mathrm{CK}$, tripotassium citrate; $\mathrm{CNa}$, trisodium citrate; HD, high dose (1889 $\mathrm{mg} / \mathrm{kg}$ )

rate in Table 2 is a little different from the apparent excretion rate in Table 1 for the following two reasons. 1) Citrate and/or its metabolites were measured in Experiment 2 but only citrate was measured in Experiment 1. 2) The total of endogenous and exogenous (administered) citrates was measured in Experiment $l$ but only the exogenous (administered) citrate was measured in Experiment 2. There was no significant difference among the groups given the same dose.

Time courses of the proportion of expiratory ${ }^{14} \mathrm{CO}_{2}$ with respect to administered ${ }^{14} \mathrm{C}$-citric acid and its salts are shown in Fig. 3-A, B.
More than $80 \%$ was excreted as expiratory ${ }^{14} \mathrm{CO}_{2}$ in the rats given the low dose while the expiratory ${ }^{14} \mathrm{CO}_{2}$ increased almost linearly for 10 hours in the rats given the high dose. The patterns of expiratory ${ }^{14} \mathrm{CO}_{2}$ excretion showed no significant difference among the groups given the same dose.

Experiment 3. Blood concentration of ${ }^{14} \mathrm{C}$-citrate and/or its metabolites as a function of time

Time courses of blood concentration of ${ }^{14} \mathrm{C}$ citrate and/or its metabolites are shown in Fig. 4-A, B. The proportion of ${ }^{14} \mathrm{C}$ radioactivity to administered ${ }^{14} \mathrm{C}$ amount was taken as the blood 


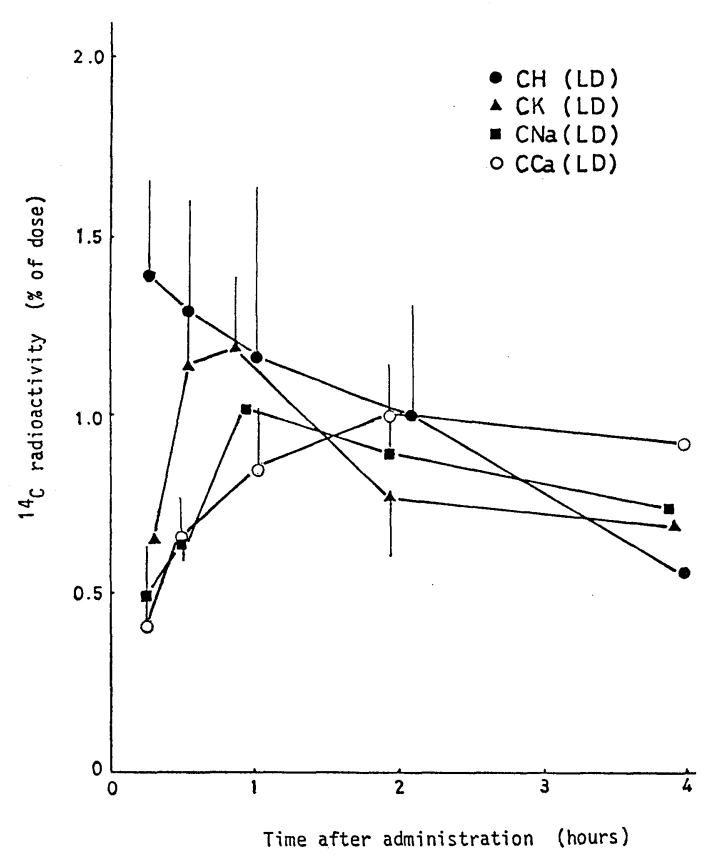

Fig. 4-A. Changes of the ${ }^{14} \mathrm{C}$ radioactivity in blood as a function of time

Each point is the mean for 3 rats and the vertical bar indicates the SEM.

Abbreviations: $\mathrm{CH}$, citric acid; $\mathrm{CK}$, tripotassium citrate; $\mathrm{CNa}$, trisodium citrate; $\mathrm{CCa}$, calcium citrate; LD, low dose (37.78 $\mathrm{mg} / \mathrm{kg}$ )

concentration here.

Fig. 4-A shows the time course of blood concentration in the rats given the low dose. Blood concentration reached the maximum after 15 minutes in the citric acid $(\mathrm{CH}(\mathrm{LD}))$ administered group, after 1 hour in the potassium citrate $(\mathrm{CK}(\mathrm{LD}))$ and sodium citrate $(\mathrm{CNa}(\mathrm{LD}))$ administered groups, and after 4 hours in the calcium citrate $(\mathrm{CCa}(\mathrm{LD}))$ administered group. There was no significant difference between $\mathrm{CK}(\mathrm{LD})$ and $\mathrm{CNa}(\mathrm{LD})$.

Time courses of the blood concentration in the rats given the high dose are shown in Fig. 4-B. Blood concentration increased during the experimental period (over 4 hours) in both the potassium salt $(\mathrm{CK}(\mathrm{HD}))$ administered group and the sodium citrate ( $\mathrm{CNa}(\mathrm{HD})$ ) administered group. The concentration was slightly higher in the $\mathrm{CK}(\mathrm{HD})$ group than in the $\mathrm{CNa}(\mathrm{HD})$ group.

The maximum values were 1.0 to $1.5 \%$ in all the groups (these values are not absolute, but

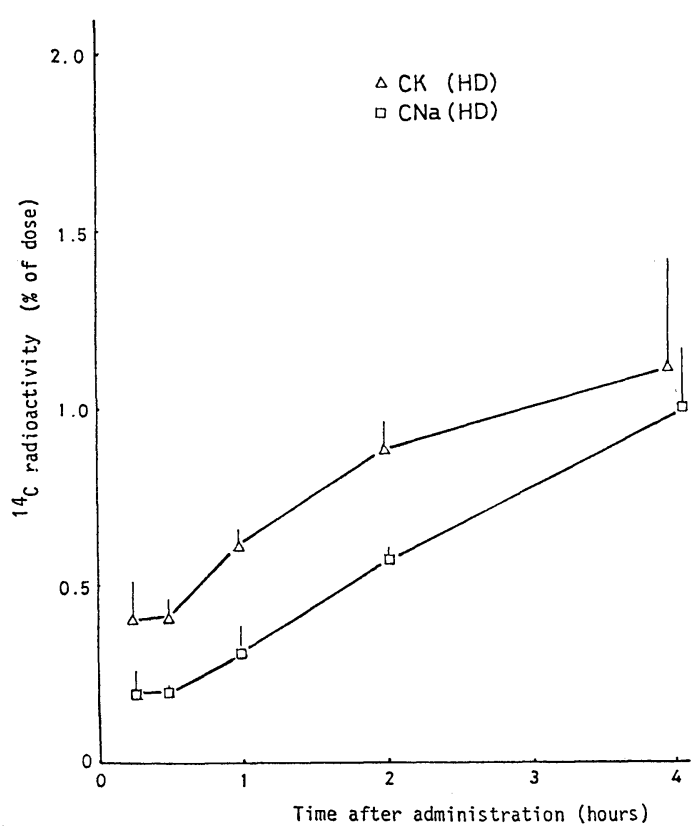

Fig. 4-B. Changes of the ${ }^{14} \mathrm{C}$ radioactivity in blood as a function of time

Each point is the mean for 3 rats and the vertical bar indicates the SEM.

Abbreviations: CK, tripotassium citrate; $\mathrm{CNa}$, trisodium citrate; $\mathrm{HD}$, high dose $(1889 \mathrm{mg} / \mathrm{kg})$

relative).

Experiment 4. Distribution of ${ }^{14} \mathrm{C}$-citrate and/ or its metabolites in tissues

The tissue distributions of ${ }^{14} \mathrm{C}$-labeled citrate and/or its metabolites at 30 minutes and 24 hours after oral administration are indicated in Table 3. The values are the proportion of ${ }^{14} \mathrm{C}$ radioactivity in tissues to the administered amount of ${ }^{14} \mathrm{C}$-labeled compound. Distribution in tissues was higher after 30 minutes than after 24 hours in all the rats. ${ }^{14} \mathrm{C}$-Citrates remaining in the gastrointestinal tract amounted to 37.6 to $47.2 \%$ in the rats given the low dose, and 61.5 to $64.3 \%$ in the rats given the high dose, while less than $3 \%$ remained in the gastrointestinal tract in all the rats. The total ${ }^{14} \mathrm{C}$ radioactivity in blood, liver, kidney, lung, stomach, small intestine and large intestine amounted to 41.6 to $51.0 \%$ after 30 minutes and 2.0 to $2.4 \%$ after 24 hours in the rats given the low dose, while the corresponding values were 64.6 to $66.8 \%$ after 30 minutes and 2.0 to $3.8 \%$ after 24 hours in the 
rats given the high dose.

There was no clear difference in the pattern of distribution among the groups given the same dose. In the rats given the high dose, the distribution in the gastrointestinal tract was higher but that in the blood was lower than those of rats given the low dose after $\mathbf{3 0}$ minutes. There was no significant difference in the patterns of distribution among all groups after 24 hours.

\section{Discussion}

Citric acid is a tricarboxylic acid, and at physiological $\mathrm{pH}$ is more than $90 \%$ ionized $^{10)}$. Citrate levels in the plasma of humans and other mammals range between 0.05 and $0.3 \mathrm{~m} M^{11)}$. Together with the liver, the kidney is the most important site for the regulation of plasma citrate, as well as of other tricarboxylic acid cycle metabolites ${ }^{12)}$. More than $90 \%$ of blood citrate is ultrafilterable, passing readily through the glomerulus ${ }^{12)}$. In man, 5 to $30 \%$ of filtered citrate is excreted ${ }^{12)}$, whereas in rats and dogs the amount is much smaller, averaging 3 to $7 \%$ in rats $^{12)}$. The proximal tubule reabsorbs between 70 and $95 \%$ of filtered citrate and returns it to the blood or metabolizes $\mathrm{it}^{12)}$. A large proportion of citrate is converted to $\mathrm{CO}_{2}$ and $\mathrm{H}_{2} \mathrm{O}^{12}$.

Many factors alter citrate excretion, particularly acid-base conditions, blood citrate levels, gastrointestinal citrate absorption, magnesium and hormones ${ }^{12)}$. In at least one instance, the change in citrate excretion occurs within minutes $^{12)}$. The urinary excretion of citrate may be increased following an oral load of citric acid or alkaline citrate, although other investigators have not found this ${ }^{13)}$. The object of this study was to investigate the metabolism of citric acid and its potassium, sodium and calcium salts. Experiments were performed 1) to determine whether there is any difference in the metabolism of citric acid and its alkaline salts and 2) to compare the metabolism of potassium citrate and sodium citrate. We obtained several interesting results as follows.

First, the excretion of urinary citrate was apparently increased when potassium and sodium citrate were administered (Table 1). The greater the amount of citrate administered, the more citrate and/or its metabolites were ex- creted in urine (Table 2). However, the increase of urinary citrate excretion was milder in the rats given citric acid and calcium citrate (Table 1). Accordingly, the metabolism of potassium and sodium citrates might differ somewhat from that of citric acid and calcium citrate at the high dose.

Second, urinary citrate excretion reached maximum after 0 to 2 hours in the rats given citric acid and potassium citrate, after 2 to 4 hours in the rats given sodium citrate, and after 4 to 6 hours in the rats given calcium citrate (Fig. 2). Blood concentration of citrate and/or its metabolites reached the maximum after 15 minutes in the rats given citric acid, after 1 hour in the rats given potassium citrate and sodium citrate, and after 2 hours in the rats given calcium citrate (Fig. 4-A). Thus, it is considered that the order of absorption rates of citric acid and its salts is as follows: citric acid $>$ potassium citrate $\geqq$ sodium citrate $>$ calcium citrate.

Third, expiratory ${ }^{14} \mathrm{CO}_{2}$ excretion increased almost linearly for 10 hours in the rats given the high dose, but reached a plateau of more than $80 \%$ within 6 hours in the rats given the low dose (Fig. 3-A, B). Blood concentration of citrate and/or its metabolites increased during 4 hours in the rats given the high dose, but reached the maximum within 2 hours in those given the low dose. In a comparison of the distributions of citrate and/or its metabolites at 30 minutes after administration of the high dose and the low dose, the distribution in the gastrointestinal tract was higher but that in blood was lower in the former case (Table 3). Therefore it is suggested that the more citric acid and its salts were administered orally, the slower was their absorption rate.

Fourth, expiratory excretion of ${ }^{14} \mathrm{CO}_{2}$ reached 76.7 to $88.9 \%$ within 24 hours in all cases (Table 2). The excretion in expired air, urine, and feces during 24 or 48 hours amounted to 88.1 to $99.5 \%$ of the administered dose (Table 2 ). The levels of citrate and/or its metabolites after 24 hours were low (Table 3). Therefore it is suggested that citric acid, potassium citrate, sodium citrate and calcium citrate are not accumulated in the body but are metabolized and excreted mainly in expired air and urine.

In conclusion, we studied the metabolism of 
Table 3. Distribution of ${ }^{14} \mathrm{C}$ Radioactivity

\begin{tabular}{|c|c|c|c|c|c|c|c|c|c|}
\hline \multirow{3}{*}{ Group } & \multirow{3}{*}{ Dose } & & \multicolumn{7}{|c|}{ Distribution ( $\%$ of dose) } \\
\hline & & & \multirow{3}{*}{$\begin{array}{c}\text { Blood } \\
0.88\end{array}$} & \multirow{3}{*}{$\begin{array}{r}\text { Kidney } \\
0.59\end{array}$} & \multirow{3}{*}{$\begin{array}{r}\text { Liver } \\
2.29\end{array}$} & \multirow{3}{*}{$\begin{array}{c}\text { Lung } \\
0.16\end{array}$} & \multirow{3}{*}{$\begin{array}{r}\text { Stomach } \\
34.86\end{array}$} & \multicolumn{2}{|c|}{ Intestine } \\
\hline & & & & & & & & Small & Large \\
\hline $\mathrm{CH} \quad(\mathrm{LD})$ & $37.78 \mathrm{mg} /$ & after 0.5 & & & & & & 1.98 & 0.80 \\
\hline CK (LD) & $10 \mu \mathrm{Ci} / \mathrm{kg}$ & hours & 0.82 & 0.57 & 1.97 & 0.40 & 39.70 & 5.88 & 1.64 \\
\hline $\mathrm{CNa}(\mathrm{LD})$ & & & 0.95 & 0.38 & 1.48 & 0.15 & 35.98 & 5.88 & 0.32 \\
\hline $\mathrm{CCa}$ (LD) & & & 1.15 & 0.83 & 1.65 & 0.17 & 42.60 & 3.01 & 0.28 \\
\hline CK (HD) & $1889 \mathrm{mg} /$ & after 0.5 & 0.28 & 0.39 & 0.66 & 1.18 & 50.18 & 12.78 & 1.30 \\
\hline $\mathrm{CNa}$ (HD) & $10 \mu \mathrm{Ci} / \mathrm{kg}$ & hours & 0.11 & 1.34 & 1.02 & 0.65 & 48.67 & 9.73 & 3.10 \\
\hline $\mathrm{CH}$ (LD) & $37.78 \mathrm{mg} /$ & after 24 & 0.34 & 0.23 & 0.56 & 0.03 & 0.00 & 0.30 & 0.53 \\
\hline CK (LD) & $10 \mu \mathrm{Ci} / \mathrm{kg}$ & hours & 0.33 & 0.18 & 0.51 & 0.04 & 0.06 & 0.42 & 0.40 \\
\hline $\mathrm{CNa}$ (LD) & & & 0.32 & 0.16 & 0.65 & 0.09 & 0.05 & 0.61 & 0.53 \\
\hline $\mathrm{CCa}(\mathrm{LD})$ & & & 0.30 & 0.29 & 0.66 & 0.04 & 0.11 & 0.35 & 0.49 \\
\hline CK (HD) & $1889 \mathrm{mg} /$ & after 24 & 0.35 & 0.12 & 0.59 & 0.04 & 0.06 & 0.31 & 0.57 \\
\hline $\mathrm{CNa}(\mathrm{HD})$ & $10 \mu \mathrm{Ci}$ & hours & 0.32 & 0.20 & 0.54 & 0.06 & 0.06 & 0.56 & 2.04 \\
\hline
\end{tabular}

Abbreviations: $\mathrm{CH}$, citric acid; $\mathrm{CK}$, tripotassium citrate; $\mathrm{CNa}$, trisodium citrate; $\mathrm{CCa}$, Calcium citrate; LD, low dose; HD, high dose

citric acid and its potassium, sodium and calcium salts in rats, and found that a large proportion of orally administered citric acid or its salts is absorbed, metabolized, and excreted mainly as expiratory $\mathrm{CO}_{2}$. No significant difference in metabolism of citric acid and its salts was found.

Studies on the safety of citric acid and its salts have been carried out from various points of view $^{1), 14), 15)}$. The $\mathrm{WHO}^{15)}$ concluded that citric acid and its calcium, potassium and sodium salts do not constitute a significant toxicological hazard to man and evaluated the acceptable daily intake for man as "not limited". Our results confirm that potassium, sodium and calcium salts of citric acid are metabolized similarly to citric acid when used at levels that are now current. It is suggested that potassium citrate is not a hazard to man at the level currently ingested from foods.

\section{Acknowledgements}

We thanks Dr. Tanaka (Head of the Division of Biological Chemistry and Reference Standards) and Dr. Takahashi (Head of the Division of Medical Chemistry) in The National Institute of Hygienic Sciences for their support of this work. We also thank the staff of the Division of Microbiology and Pharmacy in our laboratory for assistance in carrying out the animal experiment and Dr. Sekizawa (Division of Information on Chemical Safety, National Institute of Hygienic Sciences, Tokyo) for making available his research data.

\section{References}

1) FDA in USA: SGOGS-81, contract No. FDA 223-75-2004, 1 23 (1977).

2) Thunberg, T.: Physiol. Rev. 33, 1 12 (1953).

3) Federation of Food Additives: "The Japanese Standards of Food Additives" 4th Edition, p. 17 39 (1979)

4) FDA in USA: Federal Register46, 834 839 (1983).

5) Committee of Research for Daily Intake of Food Additives: "The Study about Daily Intake of Food Additives in the 60th Year of Showa" (in press).

6) Adler, S., Anderson, B., Zemolel, L.: Am. J. Physiol. 220, 986 990 (1971).

7) Jessop, N. S., Scaife, J. R.: Biochem. Soc. Trans. 13, 1222 1223 (1985).

8) Mogi, M., Nakao, M., Goto, Y., Ito, T., Matsuki, Y.: Iyakuhin Kenkyu, 17, 714 725 (1986).

9) Suzuki, T., Tazaki, K., Nakahama, H.: "Principles of Physiology III" p. 2 (1972), Kyoritsu Shuppan, Tokyo.

10) Swille, P. O., Smith, L. H., Robertson, W. G., Vahlensieck, W.: "Urolithiasis and Related Clinical Research" p. 181 188 (1985), Plenum Press, Mew York \& London.

11) Simpson, D. P.: Am. J. Physiol. 244, F223 F234 (1983).

12) Swille, P. O., Smith, L. H., Robertson, W. G. 
Vahlensieck, W.: "Urolithiasis and Related Clinical Research" p. 173 180 (1985), Plenum Press, New York \& London.

13) Swille, P. O , Smith, L. H., Robertson, W. G., Vahlensieck, W.: ibid. p. 525 532 (1985), Plenum Press, New York \& London.
14) Food and Drug Research Lab., Inc.: "Specific Literature Reviews on Generally Recognized as Safe (GRAS) Food Ingredients-Citrates" PB223850 (1973).

15) WHO: "WHO Food Additives Series No. 5" p. $170 \sim 172$ (1974). 